\title{
SHORT REPORT: RESPIRATORY SYNCYTIAL VIRUS INFECTIONS IN NORTHEASTERN BRAZIL: SEASONAL TRENDS AND GENERAL ASPECTS
}

\author{
FERNANDA E. A. MOURA,* ILA F. S. NUNES, GERALDO B. SILVA, JR., AND MARILDA M. SIQUEIRA \\ Laboratório de Virologia, Departamento de Patologia e Medicina Legal, Universidade Federal do Ceará, Fortaleza, Ceará, Brazil; \\ Laboratório de Vírus Respiratórios, Instituto Oswaldo Cruz, Rio de Janeiro, Brazil
}

\begin{abstract}
Respiratory syncytial virus (RSV) is one of the most prevalent agents of acute respiratory infections in children. Consistent data about seasonality of infections caused by this virus in Brazil proceed only from southern and southeastern regions. The purpose of this study was to determine the prevalence and the seasonal pattern of RSV infections in children living in Fortaleza city in northeastern Brazil. Nasopharyngeal aspirates of 1,950 patients attending in ambulatories, emergency room, and wards of Hospital Infantil Albert Sabin were collected and screened for RSV infections during 43 consecutive months. RSV was detected in $21 \%$ of the cases. RSV seasons in Fortaleza lasted 6 to 8 consecutive months, starting in January or February and finishing in July or August, and were associated with the rainy season.
\end{abstract}

Respiratory syncytial virus (RSV) is a well-recognized pathogen of the respiratory tract in both infants and young children. ${ }^{1-5}$ RSV causes yearly outbreaks of acute respiratory infections (ARI) in regular intervals. The association of RSV infections with the cold season has been demonstrated in regions with temperate climate, and in regions with tropical climate they can be associated or not with the rainy season. ${ }^{6-9}$ Consistent data about RSV pattern of circulation in Brazil are still limited to those obtained from studies performed in a few cities of southern and southeastern regions. ${ }^{10-12}$ This study was conducted in Fortaleza city during 43 consecutive months, from January 2001 to July 2004, with the purpose to determine the prevalence and seasonality of RSV infections. Fortaleza, the capital of the state of Ceará, northeastern Brazil, is a city of 2,250,000 inhabitants at sea level, $4^{\circ}$ south of the Equator, and with two distinct seasons: the rainy season that usually occurs in the first half of each year usually between January and May and a dry season during the rest of the year. The climate has a constant high relative humidity $(>70 \%)$ with a mean annual temperature of $27^{\circ} \mathrm{C}$. Children eligible for the study were those of any age, with clinical diagnosis of acute upper and/or lower respiratory infection within 7 days of onset, attending in ambulatory, emergence room, and wards of Hospital Infantil Albert Sabin (HIAS). Samples of nasopharyngeal secretions obtained by aspiration from each patient were processed for antigen detection by indirect immunofluorescence assay (IFA) using monoclonal antibody for RSV, as described previously. ${ }^{13}$ Statistical analysis was done with Epi-Info 6.04d and using $\chi^{2}$ for linear trends for the epidemiologic data. The statistical tests were twotailed, with a significance level of $P<0.05$. Spearman's correlation test was used to correlate RSV epidemic periods and rainy season. Informed consent was obtained from parents or legal guardians of the enrolled children. The current study was approved by the Ethics Committee of the HIAS.

A total of 1,950 samples were collected and tested by IFA for detection of RSV antigens, being 908 (46.6\%) from children attending in ambulatory, $748(38.4 \%)$ from children seen in emergence room, and $294(15 \%)$ from the hospitalized

* Address correspondence to Fernanda E. A. Moura, Laboratório de Virologia, Departamento de Patologia e Medicina Legal, Universidade Federal do Ceará, Rua Monsenhor Furtado SN, Rodolfo Teófilo, 60 441-750, Fortaleza-Ceará, Brazil. E-mail: fernandaedna@ terra.com.br ones. The prevalence of RSV was $21 \%$ (409 out of 1,950 ). The RSV seasons in Fortaleza varied from 6 to 8 months, with the first cases being observed in January (2001, 2002, and 2003) or February (2004), and the last ones detected in July or August. During four years of study, the peak of RSV infections was April, May, and June when more than $72 \%$ of all cases occurred. Monthly distribution of ARI and those caused by RSV related to rainfall pattern is shown in Figure 1. This study clearly demonstrated the statistical association between RSV activity and rainy season. Although RSV detection had increased during the rainy season, RSV peaks did not coincide with peak of rainfall in most years. The association of RSV epidemic periods with the wet seasons validates similar observations of other studies from tropical and subtropical countries with seasonal rain fall. ${ }^{5,9,10,14}$ Rainfall is the major climatic variable in Fortaleza, while temperature and relative humidity have narrow range. The lack of detection of RSV over the dry seasons or more precisely in the majority of the months of the second half of each year is a striking aspect shown in Figures 1 and 2. This observation contradicts the reported trends in other tropical areas with year-round RSV activity. ${ }^{9,15,16}$

Differences in RSV activity in tropical regions has been described. These variations range from RSV occurrence without seasonality to observation of more than one peak of RSV activity for a year of study. RSV seasons in Papua New Guinea have shown two small peaks in March and October coinciding with excessive rainfall, while in Singapore they were associated with higher environmental temperature, lower relative humidity, and higher maximal day-to-day tem-

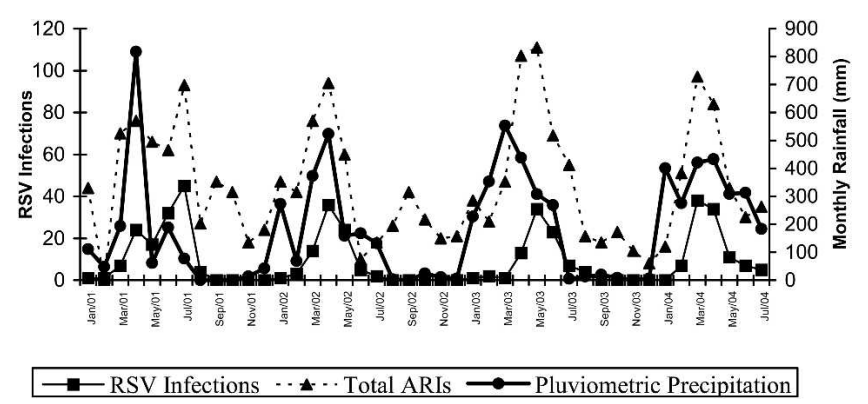

FIGURE 1. Monthly distribution of total acute respiratory infections, those due to respiratory syncytial virus and rainfall, Fortaleza, Brazil, from January 2001 to July 2004. 


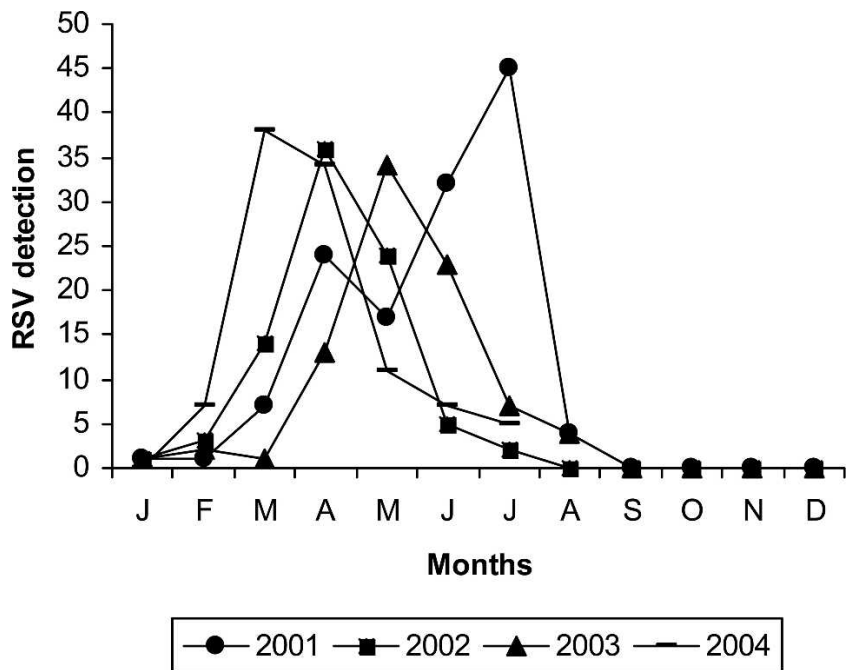

FIGURE 2. Monthly detection of respiratory syncytial virus (RSV) by year of study.

perature variation. ${ }^{9,17}$ The association of RSV seasons with the warm and rainy season has been described in Mozambique. ${ }^{5}$ The detection of RSV in all four seasons without seasonality over two consecutive years also was observed in Taiwan. ${ }^{18}$ The broad diversity climate of each region cited previously seems to contribute to a correspondent diversity of RSV activity. Climate differences observed among countries so far could be found in Brazil, the largest country of South America. The RSV occurrence is not uniform also between the Brazilian geographic regions and even among different states of the same region. In cities of the southeastern region such as Rio de Janeiro and São Paulo, with a subtropical climate, the outbreaks beginning in late March or early April reach the peak in May and last 5 months. ${ }^{11,12}$ In São Paulo city, the peak of RSV outbreaks have not been associated with the rainy seasons nor to the coldest months. ${ }^{12}$ In Vitoria city, also in the southeastern region, RSV was detected in 10 of 12 months of study, with the majority of cases concentrated from February to May. ${ }^{16}$ In northern Brazil, RSV epidemic periods reach the peak in May and June. The hallmark of RSV infections in our country, based in published data, is the occurrence of peaks of epidemic periods in the first half of the year, except in the southern region, the only one with temperate climate, where RSV infections peaked in the coldest months (July and August) and can extend until October or November. $^{10}$

Demographic features of the study population and clinical diagnostic of ARIs caused or not by RSV are shown in Table 1. The prevalence of RSV was $21 \%$, a rate similar to that seen in Brazilian studies that used IFA as diagnostic method. The higher frequency of RSV infections in patients attending in emergency room and wards $(P<0.001)$ found in this study is in keeping with previous results of several hospital-based ARI studies. ${ }^{1,10,11}$ Hospitalized children presented RSV infection more frequently than those seen in ambulatories (RR $2.59,95 \%$ CI 2.08, 3.22) and than those attending in emergency room (RR 1.67, 95\% CI 1.37, 2.04). The rate of RSV detection in children attending in ambulatories (32\%) was higher than those obtained in others studies with pediatric outpatients. ${ }^{18-21}$ A lack of detection of RSV was observed in
TABLE 1

Demographic data of RSV-infected and noninfected children

\begin{tabular}{lccr}
\hline & $\begin{array}{c}\text { Parameter } \\
+(\%)\end{array}$ & $\begin{array}{c}\text { RSV } \\
-(\%)\end{array}$ & Total \\
\hline $\begin{array}{lccr}\text { Locale of attending } \\
\text { Ambulatory }\end{array}$ & $131(32.2)$ & $777(50.4)$ & 908 \\
$\quad \begin{array}{l}\text { Emergency room } \\
\text { Ward }\end{array}$ & $167(40.6)$ & $581(37.7)$ & 748 \\
Gender & $111(27.2)$ & $183(11.9)$ & 294 \\
$\quad$ Male & $235(57.3)$ & $801(52)$ & 1,036 \\
Female & $174(42.7)$ & $740(48)$ & 914 \\
Age (months) & & & \\
$\quad$ 0-6 & $128(31.4)$ & $326(21)$ & 454 \\
6-12 & $107(26)$ & $364(23.6)$ & 471 \\
12-24 & $100(24.5)$ & $411(26.6)$ & 511 \\
24-60 & $64(15.6)$ & $303(19.5)$ & 367 \\
>60 months & $10(2.5)$ & $137(8.8)$ & 147 \\
Clinical diagnosis & & & \\
$\quad$ Upper respiratory tract infection & $127(31)$ & $796(51.6)$ & 923 \\
$\quad$ Lower respiratory tract infection & $282(69)$ & $745(48.4)$ & 1,027 \\
Total & 409 & 1541 & 1,950 \\
\hline
\end{tabular}

a household-based study also performed in Fortaleza during 29 months. ${ }^{21}$ A very low rate of detection of RSV was cited in a study with children attending day care in Salvador city, also located in northeastern Brazil. ${ }^{19}$ The results of these two studies demonstrated that rhinovirus was the most common virus detected in outpatients with ARI. Infections by RSV were identified in all age groups, but the majority (82\%) of the cases occurred in children until 2 years of age $(P<0.001)$. This high occurrence of RSV infections in the first 2 years of age has been reported consistently in the literature. ${ }^{10,11,22}$ In spite of considerable number of lower respiratory tract infections caused by RSV, our results also show RSV as an important agent of upper respiratory tract infections, mainly in children attending in ambulatories.

Although data about the pattern of circulation of some respiratory viruses in Fortaleza had been published in the early 1990s, there was a complete lack of information concerning RSV infections. ${ }^{19}$ Our results showed the high prevalence of RSV-related morbidity during the epidemic periods, confirming the rates observed in other hospital-based studies and simultaneously pointing to RSV as a important agent of ARIs also among patients attending at ambulatory. Rhinovirus has been shown as the major viral agent of ARI among pediatric outpatients from northeastern Brazil. ${ }^{19,20}$

In summary, we have shown that in Fortaleza, RSV causes regular predictable annual outbreaks with marked seasonality during the first half of each year and the rainy season. This regularity of RSV seasons in Fortaleza may prove useful to institute measures that will warrant a better attendance of patients during these periods and to adoption of effective control of these infections among hospitalized patients.

Received May 16, 2005. Accepted for publication July 27, 2005.

Acknowledgments: The American Committee on Clinical Tropical Medicine and Travellers' Health (ACCTMTH) assisted with publication expenses.

Financial support: Coordenação de Aperfeiçoamento de Pessoal de Nível Superior (CAPES), Brazil.

Authors' addresses: Fernanda E. A. Moura, Ila F. S. Nunes, and Geraldo B. Silva Jr., Laboratório de Virologia, Departamento de Patologia e Medicina Legal, Universidade Federal do Ceará, Rua 
Monsenhor Furtado SN, Rodolfo Teófilo, 60 441-750, FortalezaCeará, Brazil, Telephone: 55-021-8532888303, Fax: 55-021-85 32888316. Marilda M. Siqueira, Laboratório de Vírus Respiratórios, Instituto Oswaldo Cruz, Avenida Brasil, 4365, Rio de Janeiro, Brazil, Telephone: 55-021-2125984360, Fax: 55-021-2125739591.

Reprint requests: Fernanda E. A. Moura, Laboratório de Virologia, Departamento de Patologia e Medicina Legal, Universidade Federal do Ceará, Rua Monsenhor Furtado SN, Rodolfo Teófilo, 60 441-750, Fortaleza-Ceará, Brazil, Telephone: 55-021-8532888303, Fax: 55-02185-32888316, E-mail: fernandaedna@terra.com.br.

\section{REFERENCES}

1. Avendaño LF, Palomino MA, Larrañaga C, 2003. Surveillance for respiratory syncytial virus in infants hospitalized for respiratory infection in Chile. J Clin Micrbiol 41: 4879-4882.

2. Deshpande SA, Northern V, 2003. The clinical and health economic burden of respiratory syncytial virus disease among children under 2 years of age in a defined geographical area. Arch Dis Child 88: 1065-1069.

3. Constantopoulos AG, Kafetzis DA, Syrogiannopoulos GA, Roilides EJ, Malaka-Zafiriu EE, Sbyrakis SS, Marcopoulos ML, 2002. Burden of respiratory syncytial viral infections on paediatric hospitals: a two-year prospective epidemiological study. Eur J Clin Microbiol Infect Dis 21: 102-107.

4. Noyola DE, Rodriguez-Moreno G, Sanchez-Alvarado J, Martinez-Wagner R, Ochoa-Zavala JR, 2004. Viral etiology of lower respiratory tract infections in hospitalized children in México. Pediatr Infect Dis J 23: 118-123.

5. Loscertales MP, Roca A, Ventura PJ, Abacassamo F, Dos Santos F, Sitaube M, Menndez C, Greenwood BM, Saiz JC, Alonso PL, 2002. Epidemiology and clinical presentation of respiratory syncytial virus infection in a rural area of southern Mozambique. Pediatr Infect Dis J 21: 148-155.

6. Kim HW, Arrobio JO, Brandt CD, Jeffries BC, Pyles G, Reid JL, Chanock RM, Parrott RH, 1973. Epidemiology of respiratory syncytial virus infection in Washington, DC I. Importance of the virus in different respiratory tract disease syndromes and temporal distribution of infection. Am J Epidemiol 18: 216225.

7. Duppenthaler A, Gorgievski-Hrisoho M, Frey U, Aebi C, 2003. Two-year periodicity of respiratory syncytial virus epidemics in Switzerland. Infection 31: 75-79.

8. Berman S, Duenas A, Bedoya A, Constain V, Leon S, Borrero I, Murphy J, 1983. Acute lower respiratory tract illnesses in Cali, Colombia: a two year ambulatory study. Pediatrics 71: 210-218.

9. Heirholzer JC, Tannock GA, Heirholzer CM, 1994. Subgrouping of respiratory syncytial virus from Australia and Papua New Guinea by biological and antigenic characteristics. Arch Virol 136: $133-147$.

10. Straliotto SM, Siqueira MM, Muller RL, Fischer GB, Cunha ML,
Nestor SM, 2002. Viral etiology of acute respiratory infections among children in Porto Alegre, RS, Brazil. Rev Soc Bras Med Trop 35: 283-291.

11. Nascimento JP, Siqueira MM, Sutmoller F, Krawczuk MM, de Farias V, Ferreira V, Rodrigues MJ, 1991. Longitudinal study of acute respiratory diseases in Rio de Janeiro: occurrence of respiratory viruses during four consecutive years. Rev Inst Med Trop São Paulo 33: 287-296.

12. Vieira SE, Stewien KE, Queiroz DAO, Durigon EL, Törok TJ, Anderson LJ, Miyao CR, Hein N, Botosso VE, Pahl MM, Gilio AE, Ejzenberg B, Okay Y, 2001. Clinical Patterns and seasonal trends in respiratory syncytial virus hospitalizations in São Paulo, Brazil. Rev Inst Med Trop São Paulo 43: 125-131.

13. Moura FE, Borges LC, Portes SA, Ramos EA, Siqueira MM, 2003. Respiratory syncytial virus infections during an epidemic period in Salvador, Brazil. Description of clinical and epidemiological aspects. Mem Inst Oswaldo Cruz 98: 739-743.

14. Weber MW, Dackour R, Usen S, Schneider G, Adegbola RA, Cane P, Jaffar S, Milligan P, Greenwood BM, Whittle H, Mulholland EK, 1998. The clinical spectrum of respiratory virus disease in the Gambia. Pediatr Infect Dis J 17: 224-230.

15. Reese PE, Marchette NJ, 1991. Respiratory syncytial virus infection and prevalence of subgroups A and B in Hawaii. J Clin Microbiol 29: 2614-2615.

16. Checon RE, Siqueira MM, Lugon AK, Portes S, Dietze R, 2002. Seasonal pattern of respiratory syncytial virus in a region with tropical climate in southeastern Brazil. Am J Trop Med Hyg 67: 490-491.

17. Chew FT, Doraisingham S, Ling AE, Kumarasinghe G, Lee BW, 1998. Seasonal trends of viral respiratory tract infections in the tropics. Epidemiol Infect 121: 121-128.

18. Tsai HP, Kuo PH, Liu CC, Wang JR, 2001. Respiratory viral infections among inpatients and outpatients in Taiwan from 1997 to 1999. J Clin Microbiol 39: 111-118.

19. Souza LS, Ramos EA, Carvalho FM, Guedes VM, Souza LS, Rocha CM, Soares AB, Velloso Lde F, Macedo IS, Moura FE, Siqueira M, Fortes S, de Jesus CC, Santiago CM, Carvalho AM, Arruda E, 2003. Viral respiratory infections in young children attending day care in urban northeast Brazil. Pediatric Pulmonol 35: 184-191.

20. Lin TZ, Huang YC, Ning HC, Tsao KC, 2004. Surveillance of respiratory viral infections among pediatric outpatients in northern Taiwan. J Clin Virol 30: 81-85.

21. Arruda E, Hayden FG, McAuliffe JF, de Sousa MA, Mota SB, McAuliffe MI, Geist FC, Carvalho EP, Fernandes MC, Guerrant RL, Gwaltney JM Jr, 1991. Acute respiratory viral infections in ambulatory children of urban northeast Brazil. J Infec Dis 164: 252-258.

22. Collins PI, Chanock RM, Murphy BR, 2001. Respiratory syncytial virus disease, In: D. Knipe, P. Howley (Eds.), Fields in Virology, pp 1443-1486. 